\title{
Transthyretin Cerebrospinal Fluid Levels in Alzheimer's Disease - Is This a Biomarker for Disease Severity?
}

\author{
Sara Friederike Gloeckner ${ }^{1}$ and Inga Zerr² \\ 1. Doctoral Student; 2. Professor, Department of Neurology, University Medical School, Georg-August University Göttingen
}

DOI:10.17925/ENR.2009.04.02.17

\section{Abstract}

Alzheimer's disease $(A D)$ is the most common cause of dementia. $A \beta_{1-42}, A \beta_{1-40}$, total tau and hyperphosphorylated tau have been reported to be suitable biomarkers in the diagnosis of $A D$. Additionally, transthyretin has been suggested as a biomarker as it has been shown to inhibit $A \beta$ aggregation and the formation of senile plaques. Aggregates of $A \beta_{1-42}$ are an important hallmark of the pathogenesis of $A D$. Patients with AD show significantly lower levels of transthyretin in the cerebrospinal fluid (CSF) compared with ageing controls or patients with other kinds of dementia. Furthermore, some data indicate that transthyretin levels reflect disease severity in AD. In conclusion, recent work demonstrates the potential of transthyretin as an additional biomarker in the neurochemical differential diagnosis of $A D$.
\end{abstract}

\section{Keywords}

Dementia, Alzheimer's disease (AD), cerebrospinal fluid (CSF), transthyretin (TTR), biomarker, disease severity, transthyretic, prognosis

Disclosure: The authors have no conflicts of interest to declare.

Received: 17 February 2009 Accepted: 24 August 2009

Correspondence: Inga Zerr, Department of Neurology, Georg-August University of Göttingen, Robert-Koch-Str 40, D-37075 Göttingen, Germany.

E: Ingazerr@med.uni-goettingen.de

Alzheimer's disease (AD), described for the first time in 1906 by Alois Alzheimer, is a neurodegenerative disease and the most frequent cause of dementia worldwide. The major neuropathological hallmarks of the disease are loss of neurons and synapses, and senile plaques (extracellular aggregates primarily composed of $\beta$-amyloid; $A \beta$ ) and neurofibrillary tangles (aggregates of hyperphosphorylated forms of the microtubule-associated tau protein) throughout cortical and limbic regions of the brain. ${ }^{1}$ Definite diagnosis still requires pathology according to these criteria; however, in recent years substantial progress has been made in the area of early clinical biomarker development. The use of cerebrospinal fluid (CSF) as a testing platform seems to be very promising because the CSF protein composition reflects the pathological processes of the brain and because it is easily accessible by lumbar puncture. Some proteins have been reported to meet the criteria for a biomarker, such as $A \beta_{1-42}, A \beta_{1-40}$, total tau and hyperphosphorylated tau ( $\mathrm{p}$-tau). ${ }^{2-4}$ Another series reported transthyretin (TTR) as a potential biomarker in $\mathrm{AD}$. Whereas the aforementioned biomarkers have been studied extensively and were suggested to be included into clinical AD criteria, less information is available on TTR. This article focuses on the importance of $T R R$ in $A D$, summarises the information on the potential involvement of TTR in AD pathogenesis and highlights its role in the differential diagnosis of dementia.

\section{Transthyretin - Synthesis}

TTR is a $55 \mathrm{kDa}$ plasma homotetrameric protein that was first discovered in 1942. In the CSF, it is the main iodothyronine-binding protein, transferring $T_{4}$ from the blood into the brain across the blood-choroid plexus barrier. ${ }^{5-7}$ Serum TTR is also involved in the transport of plasma retinol-binding protein complex to vitamin A. ${ }^{8}$
TTR is synthesised in the liver and the choroid plexus of the brain, 9,10 and TTR messenger RNA (mRNA) has also been found in kidney cells. ${ }^{11}$ In the CSF it is composed of two fractions: one originating in the blood (about 10\%) and one from the choroid plexus. ${ }^{12}$ Studies on the plexus fraction are limited, but they are extremely important and urgently needed, since both morphological and functional changes in the choroid plexus are known to occur in AD. The ratio of the concentration of TTR in CSF to the concentration in serum is 200 times in excess compared with albumin. ${ }^{13}$ The concentration of TTR in serum is a sensitive indicator for malnutrition and illness owing to a reduction in its production rate in combination with its very rapid rate of disappearance from the circulation: about $50 \%$ per day. ${ }^{14}$

\section{Transthyretin and Alzheimer's Disease}

Cerebrospinal Fluid Studies

In healthy elderly people, TTR levels increase with age. ${ }^{15}$ However, there was no correlation found between CSF production and CSF total protein concentration. ${ }^{16}$ By contrast, $A D$ patients display significantly lower concentrations despite some overlap between AD patients and ageing controls. A potential explanation for this phenomenon is that $A D$ is associated with the flattening of choroid plexus epithelial cells and with an increase in the diameter of the basal lamina. ${ }^{17}$ As both structures are involved in the production and filtration of CSF, it is likely that there is an association between morphological changes in the choroid plexus and a reduced TTR secretion rate. ${ }^{17}$

\section{Pathology/Effect on A $\beta$ Aggregation}

Aggregates of the amyloidogenic $\left(A \beta_{1-42}\right)$ peptide play a major role in the pathogenesis of $A D$, although the precise mechanism is unclear. ${ }^{18}$ 
Figure 1: Transthyretin Levels in Cerebrospinal Fluid

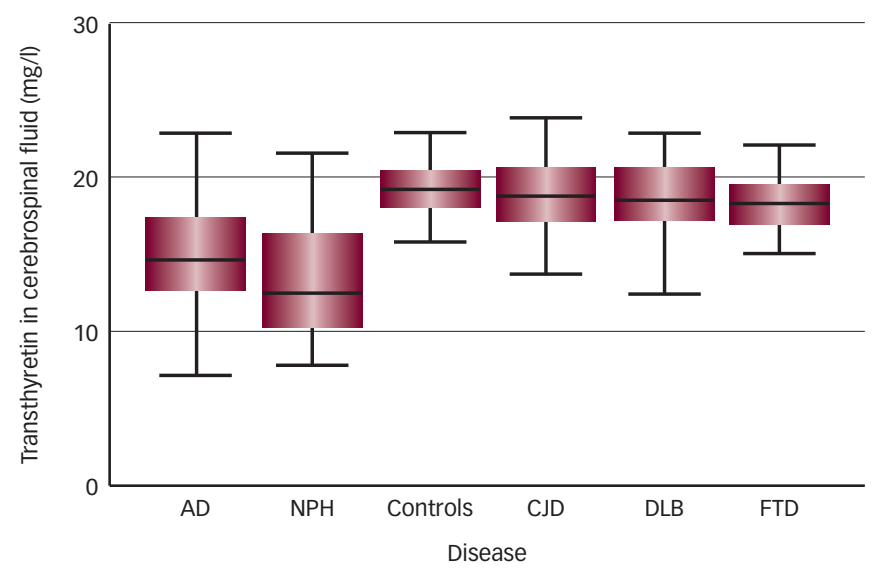

$A D=$ Alzheimer's disease; $N P H=$ normal pressure hydrocephalus; $C J D=$ Creutzfeldt-Jakob disease $; D B=$ dementia with Lewy bodies; FTD = frontotemporal dementia.

Figure 2: Transthyretin Levels in Different Stages of Alzheimer's Disease

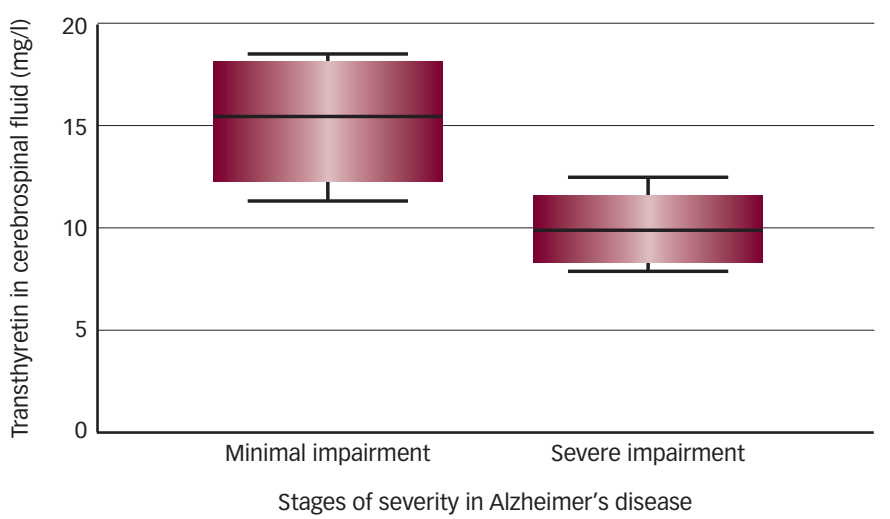

TTR plays an important role in keeping intra-cerebral proteins such as amyloid fibrils in a soluble form, and some in vitro experiments have demonstrated that TTR inhibits $A \beta$ aggregation and the formation of senile plaques. ${ }^{19-24}$ Synthetic unlabelled A $\beta$ was incubated with CSF, TTR or albumin and analysed later using Western blot techniques with antiTTR and anti-AC antibodies. TTR-A $\beta$ complexes with an apparent molecular mass of 30kDa were observed under non-reducing conditions, ${ }^{19}$ which points towards high-affinity binding between those molecules. Transmission electron microscope (TEM) and light scattering analysis showed that TTR inhibited A $\beta$ aggregation, and tryptophan (Trp) fluorescence quenching experiments also showed that full-length $A \beta$, but not non-aggregating $A \beta$ fragments $\left(A \beta_{|-| \mid}\right)$and $A \beta,^{12-28}$ quench TTR's Trp fluorescence. ${ }^{25}$

In human CSF under physiological conditions, TTR forms soluble complexes by binding to $A \beta$ protein. An important inhibition of $A \beta$ aggregation is found at a molar ratio of 1:300, which suggests that TTR in CSF could be the major $A \beta$-binding protein and protects against $A \beta$ deposition. ${ }^{19,20,26}$ As CSF concentrations of $A \beta$ have been reported to increase with age, ${ }_{1}^{29}$ the concomitant increase in TTR concentrations with age could be an important feature maintaining $A \beta$ in soluble complexes. In $A D$, this physiological sequestration could be imperfect owing to inadequate concentrations of TTR or potentially some TTR modifications, the latter being possibly related to epithelial atrophy in the choroid plexus in patients with late-onset AD. ${ }^{15}$
Table 1: Transthyretin Concentrations in Alzheimer's Disease Patients Compared with Healthy Controls in Various Studies

\begin{tabular}{|c|c|c|}
\hline Author & Disease & Biomarker/Methods \\
\hline $\begin{array}{l}\text { Gloeckner } \\
\text { et al., } 2008^{30}\end{array}$ & $\begin{array}{l}\text { Controls }(n=19) \\
\text { AD }(n=23) \\
\text { CJD }(n=18) \\
\text { DLB }(n=23) \\
\text { FTD }(n=10) \\
\text { NPH }(n=13)\end{array}$ & $\begin{array}{l}\text { Decreased concentration of TTR in } \\
\text { AD and NPH in comparison with } \\
\text { controls, CJD, DLB and FTD }\end{array}$ \\
\hline $\begin{array}{l}\text { Abdi et al., } \\
2006^{34}\end{array}$ & $\begin{array}{l}\text { Group of AD } \\
(n=10) \text { versus } \\
10 \text { control group } \\
(n=10) \text { pooled samples } \\
\text { Group of DLB } \\
(n=5) \text { versus } 10 \\
\text { control group } \\
(n=10) \text { pooled samples }\end{array}$ & $\begin{array}{l}\text { TTR precursor: ratio=1.55 } \\
\text { Quantitative proteomic iTRAQ }\end{array}$ \\
\hline $\begin{array}{l}\text { Biroccio } \\
\text { et al., } 2006^{35}\end{array}$ & $\begin{array}{l}\text { Group of }(n=39) A D \\
\text { versus control } \\
\text { group ( } n=27) \\
\text { individual samples }\end{array}$ & $\begin{array}{l}\text { Oxidised forms of TTR are } \\
\text { significantly less abundant in } \\
\text { the AD group }\end{array}$ \\
\hline $\begin{array}{l}\text { Castaño } \\
\text { et al., } 2006^{31}\end{array}$ & $\begin{array}{l}\text { Group of } A D(n=43) \\
\text { versus } A D ; \text { control } \\
\text { group ( } n=43 \text { ) } \\
\text { individual samples }\end{array}$ & $\begin{array}{l}\text { Decreased concentration of TTR in } \\
\text { using 2D gel electrophoresis } \\
\text { and post mortem CSF }\end{array}$ \\
\hline $\begin{array}{l}\text { Puchades } \\
\text { et al., } 2003^{36}\end{array}$ & $\begin{array}{l}\text { Group of AD }(n=7) \\
\text { versus control group } \\
(n=7) \text { pooled samples }\end{array}$ & $\begin{array}{l}\text { Decreased concentration of TTR in } \\
A D \text {, quantitative proteomic }\end{array}$ \\
\hline $\begin{array}{l}\text { Davidsson } \\
\text { et al., } 2002^{37}\end{array}$ & $\begin{array}{l}\text { Group of } A D(n=15) \\
\text { versus control group } \\
(n=12) \text { individual } \\
\text { samples }\end{array}$ & $\begin{array}{l}\text { Increased concentration of TTR in } \\
A D \text {, quantitative proteomic }\end{array}$ \\
\hline $\begin{array}{l}\text { Riisoen et al., } \\
1988^{13}\end{array}$ & $\begin{array}{l}\text { Group of } A D(n=24) \\
\text { versus control group } \\
(n=47) \text { individual } \\
\text { samples }\end{array}$ & $\begin{array}{l}\text { Decreased concentration of TTR } \\
\text { in } A D\end{array}$ \\
\hline $\begin{array}{l}\text { Merched } \\
\text { et al., } 1998^{22}\end{array}$ & $\begin{array}{l}\text { Group of } A D(n=20) \\
\text { control group }(n=10) \\
\text { versus individual samples }\end{array}$ & $\begin{array}{l}\text { Decreased concentration of TTR } \\
\text { in } A D\end{array}$ \\
\hline
\end{tabular}

$A D=$ Alzheimer's disease; $T T R=$ transthyretin; $N P H=$ normal pressure hydrocephalus $C J D=$ Creutzfeldt-Jakob disease; $D L B=$ dementia with Lewy bodies; $F T D=$ frontotemporal dementia; ITRAQ = isobaric tag for relative and absolute quantitation; CSF $=$ cerebrospinal fluid.

\section{In Vivo and In Vitro Experiments}

In 2008, Buxbaum et al. obtained in vitro evidence of direct protein-protein interaction between TTR and A $\beta$ aggregates. These findings suggest that TTR is protective because of its capacity to bind toxic or pre-toxic $A \beta$ aggregates in both the intracellular and extracellular environment in a chaperone-like manner. Older APP 23 transgenic mice showed better cognitive function carrying multiple copies of human wild-type TTR gene. Subsequent experiments confirmed this effect. Expressing the APP 23 gene in the absence of MTTR, these mice showed immunohistochemical evidence of increased A $\beta$ deposition relative to APP 23 animals with an active endogenous TTR gene. This study also demonstrated that both hTTR and $\mathrm{mTTR}$ bind $A \beta_{1-40}$ and $A \beta_{1-42 .}{ }^{18}$

\section{Transthyretin as a Biomarker for Alzheimer's Disease}

Most of the literature described reduced levels of TTR in patients with $A D$. TTR levels in the CSF of patients with $A D$ are shown to be 
reduced in comparison with patients without dementia. ${ }^{13,2,27}$ Other studies have reported decreased TTR concentrations in the CSF of patients with depression and normal pressure hydrocephalus $(\mathrm{NPH}){ }^{28,30}$ Although hampered by an artificial study design, similar results were achieved for post mortem CSF in AD. ${ }^{31}$ In other neurodegenerative diseases, normal concentrations of TTR are detected. ${ }^{30}$ Table 1 summarises the data available on TTR from CSF studies. TTR levels are significantly reduced in the CSF of patients with $\mathrm{AD}$ and NPH compared with controls and other dementia, and TTR CSF values in AD did not differ significantly from those in NPH patients (see Figure 1). ${ }^{30}$ TTR levels did not correlate with tau, $A \beta_{1-40}$ or $A \beta_{1-42}$ CSF $^{30}$

Several attempts have been made to identify parameters that might reflect disease severity in $\mathrm{AD}$. Studies on this subject are limited and contradictory results have been obtained so far. Both positive and negative associations have been reported. Increased levels of p-tau and tau were reported to reflect disease severity in $A D$ in a study that analysed the abundance of symptoms in $A D$ and low levels of $A \beta_{1-42}$. The investigators found a higher risk of early death in $A D$ in those with low $A \beta_{1-42}$, and the follow-up patients who died had significantly lower levels of $A \beta_{1-42}$ and significantly higher concentrations of tau. ${ }^{32}$ By contrast, Haense et al. ${ }^{33}$ found no associations between tau and p-tau with dementia severity in AD. In another study that analysed tau, $A \beta_{1-42}$ and TTR in the same population, clear differences between biomarkers were elucidated. Whereas no association of dementia severity with tau and $A \beta_{1-42}$ levels were detected, this was clearly observed for TTR: patients with severe AD showed a significantly lower TTR concentration $(p=0.05)$ compared with mild cognitive impairment or mild dementia. At a cutoff of $15 \mathrm{mg} / \mathrm{l}$ both stages could be discriminated, with a sensitivity of $91 \%$ and a specificity of $75 \%$ (Youden=0.66). Such an effect was not seen in patients with NPH (see Figure 2) ${ }^{30}$ In summary, TTR levels have been demonstrated to be selectively decreased in $A D$ compared with other dementias. In addition, some data indicate that levels reflect disease severity in $A D$, which makes this protein an interesting biomarker for $A D$ diagnosis. Studies on early AD stages are lacking so far, and more must follow.

Inga Zerr is a Professor in the Department of Neurology at the University Medica School, Georg-August University Göttingen. She is Head of the Dementia Outpatients Section and Head of the National Reference Centre for Prion Diseases in Germany. Her major research interests include early biomarker development in dementia, at proteomic, genomic or brain imaging levels. Professor Zerr holds various national and international grants on prion diseases and dementia research and is co-ordinating an EC-funded project on biomarker development. She studied medicine at the Georg August University in Göttingen, where she started her scientific career in the Department of Neurology in 1993
1. Selkoe DJ, Alzheimer's disease, Handb Clin Neurol, 2002;89:245-60.

2. Blennow K, Vanmechelen $\mathrm{E}$, Hempel H, CSF total tau, Abeta42 and phosphorylated tau protein as biomarkers for Alzheimer's disease, Mol Neurobiol, 2001:24:87-97.

3. Selkoe DJ, Biochemistry and molecular biology of amyloid B-protein and the mechanism of Alzheimer's disease, Handb Clin Neurol, 2008:89:245-60.

4. Paraskevas GP, Kapaki E, Papageorgiou SG, et al., CSF biomarker profile and diagnostic value in vascular dementia, Eur J Neurol, 2009;16(2):205-11.

5. Schreiber G, Aldred AR, Jaworowski A, et al., Thyroxine transport from blood to brain via transthyretin synthesis in choroids plexus, Am J Physiol, 1990;258(2 Pt 2):R338-45.

6. Dratman MB, Crutchfield FL, Schoenhoff MB, Transport of iodothyronines from the bloodstream to brain: contributions by blood: brain and choroids:cerebrospinal fluid barriers, Brain Research, 1991;554:229-36.

7. Chanoine JP, Alex S, Fang SL, et al., Role of transthyretin in the transport of thyroxine from the blood to the choroid plexus, the cerebrospinal fluid, and the brain, Endocrinology 1992;130(2):933-8.

8. Monaco $\mathrm{HL}$, The transthyretin-retinol-binding protein complex, Biochem Biophys Acta, 2000:1482(1-2):65-77.

9. Soprano DR, Herbert J, Soprano KJ, et al., Demonstration of transthyretin mRNA in the brain and other extrahepatic tissues in the rat, J Biol Chem, 1985;260(21):11793-8.

10. Aldred AR, Brack CM, Schreiber $G$, The cerebral expression of plasma protein genes in different species. Comparative Biochemistry and Physiology Part B, Biochemistry and Molecular Biology, 1995;111:1-15.

11. Wakasugi $S$, Maeda S, Shimada $K$, Structure and expression of the mouse prealbumin gene, Biochem, 1986;100:49-58.

12. Reiber $\mathrm{H}$, Dynamics of brain-derived proteins in cerebrospinal fluid, Clin Chim Acta, 2001;310(2):173-86.

13. Riisoen H. Reduced prealbumin (transthyretin) in CSF of severely demented patients with Alzheimers's disease Acta Neurol Scand, 1988;78:455-9.

14. Robbins J, Transthyretin from Discovery to Now, Clin Chem Lab Med, 2002;40(12):1183-90.

15. Serot JM, Christmann D, Dubost T, Couturier M,
Cerebrospinal fluid transthyretin: aging and late onset Alzheimer's disease, J Neurol Neurosurg Psychiatry , 1997;63(4):506-8

16. May C, Kaye JA, Atack JR, Schapiro MB, et al., Cerebrospinal fluid production is reduced in healthy aging, Neurology, 1990;40:500-503.

17. Serot J-M, Béné M-C, Foliguet B, Faure GC, Morphological alterations of the choroid plexus in late-onset Alzheimer's disease, Acta Neuropathol, 2000;99:105-8.

18. Buxbaum JN, Ye Z, Reixach N, et al., Transthyretin protects Alzheimer's mice from the behavioral and biochemical effects of AB toxicity, Proc Natl Acad Sci U S A, 2008; 105(7): 2681-6.

19. Schwarzmann AL, Gregori L, Vitek MP, et al., Transthyretin sequesters amyloid-protein and prevents amyloid formation, Proc Natl Acad Sci U S A, 1994:91:8368-72

20. Schwarzmann $A L$, Goldgaber $D$, Interaction of Transthyretin with amyloid beta-protein: binding and inhibition of amyloid formation, Ciba Found Symp, 1996:146-64.

21. Schwarzmann AL, Tsiper M, Gregori L, et al., Selection of peptides to the amyloid b-protein reveals potential inhibitors of amyloid formation, Amyloid 2005:12(4):199-209.

22. Merched A, Serot JM, Visvikis S, et al., Apolipoprotein E, transthyretin and actin in the CSF of Alzheimer's patients: relation with the senile plaques and cytoskeleton biochemistry, FEBS Lett, 1998;425(2):225-8.

23. Stein $T D$, Johnson JA, Lack of neurodegeneration in transgnic mice overexpressing mutant amyloid precursor protein is associated with increased levels of transthyretin and the activations of cell survival pathways, I Neurosci, 2002;22:7380-88

24. Choi SH, Leight SN, Lee VMY, et al., Accelerated AB deposition in APPswe/PS1deltaE9 mice with hemizyhous deletions of TTR (transthyretin), J Neurosci, 2007:27(26):7006-10.

25. Liu L, Murphy RM, Kinetics of inhibition of B-Amyloid aggregation by transthyretin, Biochem, 2006;45:15702-9

26. Sousa JC, Cardoso I, Marques F, et al., Transthyretin and Alzheimer's disease: Where in the brain?, Neurobiol Aging, 2006;12.
27. Merched A, Blain H, Visvikis S, et al., Cerebrospinal fluid apolipoprotein $\mathrm{E}$ level is increased in late-onset Alzheimer's disease, I Neurol Sci, 1997;145:33-9.

28. Sullivan GM, Mann JJ, Oquendo MA, et al., Low cerebrospinal fluid transthyretin levels in depression: correlations with suicidal ideation and low serotonin function, Biol Psychiatry, 2006;60:500-506.

29. Van Gool WA, Schenk DB, Bolhuis PA, Concentrations of amyloid-beta protein in cerebrospinal fluid increase with age in patients free from neurodegenerative disease, Neurosci Lett, 1994:172:122-4.

30. Gloeckner SF, Meyne F, Wagner F, et al., Quantitative analysis of transthyretin, tau and amyloid-beta in patients with dementia, J Alzheimers Dis, 2008;14(1):17-25

31. Castano EM, Roher $A E$, Esh CL, et al., Comparative proteomics of cerebrospinal fluid in neuropathologicallyconfirmed Alzheimer's disease and non-demented elderly subjects, Neurological Research March, 2006;28(2):155-63.

32. Wallin AK, Blennow $K$, Andreasen $N$, Minthon L, CSF biomarkers for Alzheimer's Disease: levels of betaamyloid, tau, phosphorylated tau relate to clinica symptoms and survival, Dement Geriatr Cogn Disord, 2006;21(3):131-8.

33. Haense C, Buerger K, Kalbe E, et al., CSF total and phosphorylated tau protein, regional glucose metabolism and dementia severity in Alzheimer's disease, Eur J Neurol, 2008:15(11):1155-61.

34. Abdi F, Quinn JF, Jankovic J, et al., Detection of biomarkers with multiplex quantitave proteomic platform in cerebrospinal fluid of patients with neurodegenerative disorders, J Alzheimers Dis, 2006;9:293-348.

35. Biroccio A, del Boccio P, Panella M, et al., Differential posttranslational modifications of transthyretin in Alzheimers's disease. A study of the cerebral spinal fluid, Proteomics 2006;6:2305-13

36. Puchades $\mathrm{M}$, Hansson $\mathrm{SF}$, Nisson $\mathrm{CL}$, et al., Proteomic studies of potential cerebrospinal fluid protein markers for Alzheimer's disease, Brain Res Mol Brain Res, 2003;118: 140-46.

37. Davidsson P, Westerman-Brinkmalm A, Nilsson $\mathrm{C}$, et al., Proteome analysis of cerebrospinal fluid proteins in Alzheimer patients, Neuroreport, 2002;13:611-15. 